\title{
Sciendo
}

\section{The Laws of Motecuhzoma Ilhuicamina}

\author{
PETER VYŠNÝ \\ Department of Legal History \\ Trnava University, Trnava, Slovak Republic \\ petervysny@hotmail.com
}

\begin{abstract}
The article deals with contents, as well as social contexts and functions of sixteen laws enacted by Motecuhzoma llhuicamina or Motecuhzoma I, the fifth ruler (ruled ca. 1440-1460 $A D)$ of a pre-Hispanic city-state Tenochtitlan, the principal capital of the Aztec Empire. The author also focuses on the problem of Motecuhzoma I's laws' factual enforcement and discusses its possible limits.
\end{abstract}

The enactment of Motecuhzoma I's laws was an important part of state formation process in Tenochtitlan. These laws reinforced the internal hierarchy of Tenochtitlan society and the privileged social position of a tiny ruling class (ruler, nobles by birth, merited non-noble warriors and their quasi-noble descendants), particularly by excluding masses of ordinary people from the exercise of political power, as well as the acquisition, ownership and public display of the so-called "prestige objects", which were markers of a higher social status (i.e. belonging to the ruling class). Further they established a complex state apparatus of Tenochtitlan (a system of both central and local city-state administration and judiciary), which was headed by a ruler (tlatoani). The laws also helped spread Tenochtitlan official ideology of a religious nature among the population, as they created a mechanism to introduce virtually all nobles and commoners (of both sexes) to the ideology (public schools compulsory attended by all later pubertal and adolescent youth of Tenochtitlan), as well as an organization of priests who dramatized the ideological doctrines by their (mostly public) ritual performancies. Finally, there were also laws concerning the punishment of adulterers and thieves. The factual enforcement of Motecuhzoma I's laws by Tenochtitlan ruler/state apparatus was limited due to several reasons, e.g. the rise of local autonomous and autarchic 
socioeconomic units resisting to some degree the power of state and the law enacted by the state.

KEY WORDS: pre-Hispanic period, Tenochtitlan, Motecuhzoma Ilhuicamina, Motecuhzoma's laws, Motecuhzoma's laws'contents, Motecuhzoma's laws'social contexts and functions

\section{Introduction}

Motecuhzoma Ilhuicamina or Motecuhzoma I (ruled about 1440-1469 AD), the fifth ruler (tla[h]toani; plur. tla[h]toque) of the pre-Hispanic Mexican Valley city-state Tenochtitlan, ${ }^{1}$ principal capital of the Aztec Empire, ${ }^{2}$ is reported in historical sources not only as a capable statesman and successful conqueror, but also as a legislator. Among his sixteen documented laws, called "Motecuhzoma's laws" in the present article, were: five laws related to the state organization and ideology of Tenochtitlan, namely the office of tlatoani, city-state administration and judiciary, public education based on compulsory school attendance and priests performing the state cult; nine sumptuary laws, i.e. laws regulating the acquisition, ownership and public display of the so-called "prestige objects", which, inter alia, established and reinforced, respectively, a hierarchy of Tenochtitlan inhabitants; and two penal laws, one concerning the adultery and another one the theft. All addressees of Motecuhzoma's laws were men.

Motecuhzoma's laws were enacted - according to a chronicle with a general consent of Tenochtitlan, as well as other city-states' rulers and elites, with a stamp of divine approval and having a systematic support of the power of the state (DURÁN 1994:208, 210-211) during an internal sociopolitical transformation in Tenochtitlan - shortly said, a pre-state

$1 \quad$ On Tenochtitlan rulers (kings) see GILLESPIE 1993.

2 The Aztec Empire, also called Triple Alliance Empire, had been built by three allied neighbouring city-states Tenochtitlan, Texcoco and Tlacopan from the second quarter of the $15^{\text {th }}$ century to the Spanish conquest of the Empire (1519-1521) in both central and southern parts of today's Mexico. Each city-state was Aztec Empire's capital, however, during the second half of the $15^{\text {th }}$ century Tenochtitlan's political, military, ecomomic and ideological power increased considerably and Tenochtitlan became the principal capital. The basic residential, sociopolitical and economic unit within the Aztec Empire was a city-state (altepetl; plur. altepeme[h]). On Aztec Empire in general see BERDAN et al. 1996; CARRASCO 1996.

DOI: 10.2478/eas-2018-0012 C University of SS. Cyril and Methodius in Trnava. All rights reserved. 
chiefdom-like society evolved to a state ${ }^{3}$, that had started with the reign of Motecuhzoma's predecessor Itzcoatl (ruled about 1428-1440 AD) and ended under the rule of Motecuhzoma I. Due to this transformation, and especially due to Motecuhzoma's laws as an integral part of it, a strongly stratified society, a complex state organization, as well as an elaborated state ideology, emerged in Tenochtitlan. Subsequently, Motecuhzoma's laws had been used, among other means, to enforce the new social order of Tenochtitlan. However the application of Motecuhzoma's sumptuary laws by tlatoani, i.e. the state apparatus, was rather limited in actual everyday life of Tenochtitlan inhabitants, as both elites and ordinary people were acquiring certain important prestige objects regardless these laws and tlatoani (the state) who theoretically (but not in practice) was the only distributor of prestige goods (ANAWALT 1980; BERDAN 2014:272; OFFNER 2017).

Based on historical sources and secondary literature providing information about Motecuhzoma's laws and related topics I shall examine the contents and the (intertwined) social, political, economic, religious and ideological contexts of these laws in the present article. The exploration of Motecuhzoma's laws in the article is preceded by a terminological note and a brief characteristic of historical sources informing about Motecuhzoma's laws.

The article is not intended as an exhaustive analysis of Motecuhzoma's laws. It is rather aimed at attracting attention to an issue which is almost unknown to legal historians, although it represents a remarkable and quite complex case study of the phenomenon of pre-modern codification of law.

\section{Terminological note}

Before we proceed, one terminological clarification should be made. It concerns the addressees of Motecuhzoma's laws who were, first, the inhabitants of Tenochtitlan, and, second, the inhabitants and especially the rulers, elites and warriors with merits of the citystates (altepeme; sing. altepetl) that existed both inside and outside the core area of the Aztec

3 On the process of state formation in Tenochtitlan see e.g. BRUMFIEL 1983:261-284; KURTZ 1978:169-190; VYŠNÝ 2012.

DOI: 10.2478/eas-2018-0012 C University of SS. Cyril and Methodius in Trnava. All rights reserved. 
Empire, i.e. the Mexican Valley (Valle de México), main part of broader Mesoamerican ${ }^{4}$ region known as Central Mexico (Centro de México).

Scholars call the inhabitants of Tenochtitlan "Aztecs", "Mexica(h)", "Tenochca(h)" or "Mexica(h)-Tenochca(h)". I prefer here the denomination "Tenochca", since it is the only term to apply exclusively on Tenochtitlan population. Although the denomination "Aztecs" is wide-spread (especially in Europe and the U.S.A.), the way scholars use it is not unified: some scholars call "Aztecs" the inhabitants of Tenochtitlan, others the inhabitants of the first (city-state of Tenochtitlan), second (city-state of Texcoco) and third (city-state of Tlacopan) capital of the Aztec Empire, and still others virtually all Nahuas. Nahuas were a dominant central Mexican native culture composed of approximately 20 ethnic groups (SMITH 2012:4), including the Tenochca (or Mexica) as one such group. Nahuas lived in many citystates, most of which became parts of the Aztec Empire.

To name the Tenochca "Mexica" (frequently "mexicanos", i.e. Mexicans in historical sources) is also possible, but to Mexica belonged the Tlatelolca as well, who were the immediate northern neighbours of Tenochca, living in an initially independent city-state of Tlatelolco, which was later (in 1473) annexed by Tenochtitlan. Therefore, the term "MexicaTenochca" is more precise than "Mexica", when refering to the Tenochca only, but I prefer to it the simpler term "Tenochca".

The ethnonym "Tenochca" comes from nahuatl, the language of the Nahuas. "Tenochca" is plural. The singular form is "Tenochcatl".

\section{Historical sources informing about Motecuhzoma's laws}

The most complete and systematic information about Motecuhzoma's laws provides the Historia de las Indias de Nueva España e Islas de Tierra Firme [The History of the Indies of New Spain] (DURÁN 2002, I:264-267; see also DURÁN 2002, II:118-124), a historical chronicle composed in New Spain by Dominican friar Diego Durán (1537?-1588) of Spanish descent between 1579 and 1581. According to Miguel León-Portilla (LEÓN-PORTILLA et al. 2013, 1:123-124) this information is credible since Durán's Historia is based on authentic

$4 \quad$ Pre-Hispanic Mesoamerica was a cultural historical area on the American continent. It covered the territory between approximately the $22^{\text {nd }}$ and the $10^{\text {th }}$ grade of northern latitude (e.g. KATZ 1989:31). 
Tenochca and other Nahuas' historical traditions, ${ }^{5}$ both written in Nahua scripture ${ }^{6}$ and oral, that Durán had systematically consulted before he wrote down his work.

The native historical traditions upon which Durán's chronicle should be based are to be associated with a hypothetic but very probably once existing and now lost Crónica $X$ [Chronicle $X$ ], an early $16^{\text {th }}$ century (post-conquest) primary historical source of Nahua provenience (BARLOW 1945:65-87; PEPERSTRAETE 2007; TENA 1997, 2:163-178). Crónica X [Chronicle X] should be a native (Nahua) prototype not only of Durán's Historia, but also of some other sources, notably the Crónica Mexicana ${ }^{7}$ [Mexican Chronicle] (c. 1598) of tlatoani Motecuhzoma II Xocoyotzin's (ruled 1502-1520) grandson H(F)ernando Alvarado Tezozomoc (c. 1525-c.1610), the two versions of the original work of Jesuit Juan de Tovar (1543-1623), ${ }^{8}$ known as Manuscrito de Tovar [Tovar manuscript] and Códice Ramírez [Ramírez Codex] (both around 1585), and the Historia natural y moral de las Indias [The Natural and Moral History of the Indies] (1590) of Jesuit José de Acosta (1539/15401600).

I have no doubt that the historical traditions utilized by Durán to compose his Historia were authentic, i.e. of Nahua origin, but I wonder if they would reflect the "historical truth" entirely, considering the pre-Hispanic history of Tenochtitlan (as well as of other Nahua citystates) was manipulated and to some extent even artificially fabricated both before and after the Spanish conquest of the Aztec Empire.

Before the conquest, tlatoani Itzcoatl ordered all previous historical records (in Nahua writing) be burned and created a new version of Tenochca history that legitimized the beginning expansion and the internal sociopolitical transformation (development towards a

5 On Nahua historiography and other literature genres see BOONE 2000, 2007; GARIBAY 2007.

$6 \quad$ Nahua scripture consisted of pictograms, ideograms, logograms, and to a very limited extent also of phonetic elements (LOCKHART 1992:327-330).

7 Crónica Mexicana [Mexican Chronicle] describes the reign of Motecuhzoma I at considerable length (see TEZOZOMOC 1997: 120ff.), while frequently referring to various prestige objects which were both extracted (as tribute of the conquered city-states) and distributed (as reward for Tenochca elites and non-noble warriors with military merits) by this tlatoani. The distribution of such objects was regulated by several strict rules according to Crónica Mexicana (cf. TEZOZOMOC 1997:174ff.), i.e. by sumptuary laws, which substantively coincide with Motecuhzoma's sumptuary laws registred in Durán's Historia (DURÁN 1994:208ff.).

8 Tovar's original work had the following title: Historia de la venida de los indios a poblar a México de las partes remotas de Occidente los sucesos y perigrinaciones del camino a su gobierno, ídolos y templos de ellos, ritos, ceremonias y calendarios de los tiempos. 
stratified society and a state organization) of Tenochtitlan (CASTAÑEDA DE LA PAZ 2005:115-147; LÓPEZ AUSTIN 1998:173-176; VYŠNÝ 2012:42ff.). This event had surely influenced the native traditions upon which Durán based his Historia.

After the conquest, Spaniards as well as Nahuas (Nahua local elites, respectively) had been modifying along with "inventing" the pre-Hispanic history in order to justify the conquest (Spaniards), to legitimize their specific political and economical interests (Spanish colonists as well as Nahua local elites) and the like (BERDAN 2014; FLORESCANO 1999; LOCKHART 1992; ROZAT DUPEYRON 1993; WOOD 1998:201-231), which also could influence the source material involved in Durán's chronicle. The same might result from a more or less hybrid character of concrete Nahua historical traditions that was due to a certain fusion or mutual influence of these and Spanish traditions (NAVARRETE LINARES 1997:155-179; SALOMONS 2006:1192-1315). For example, in Durán's Historia, including the text of Motecuhzoma's laws, as well as in other sources, are frequently used Spanish concepts and terms to describe various aspects of Nahua culture which distorts, to some extent, its image.

It also should be mentioned that the native fundament (Nahua historical traditions) of Durán's chronicle and other alphabetical sources does not guarantee automatically a certain higher degree of their credibility. Nahua historical traditions, both oral and those captured in Nahua scripture after the Spanish conquest of the Aztec Empire (to some extent upon now lost preHispanic prototypes), were transcribed into the alphabetical sources (BOONE 2000:6-7), whereby such transcription was surely connected with Spanish cultural influences on the transcribed contents (i.e. Nahua authentic forms of expression) and unconscious, as well as conscious manipulation, and even fabrication, of historical facts (FLORESCANO 1999:211ff.). On the other hand some scholars have argued persuasively that the criticism and scepticism towards the textual sources based on a transcription of Nahua oral and in Nahua scripture registered traditions, resting upon the premise that the transcription was indeed a very imperfect translation, may be overdue in many cases (BERDAN 2014:6-7; LEÓN-PORTILLA 1993:397ff.).

Last but not least, it is possible that Nahua historical traditions modified, to some extent, Nahua pre-Hispanic past in order to accord with some preferred narrative patterns which, for example, glorified the consolidation of Tenochtitlan city-state and the establishment of the Aztec Empire and in this way could attribute the enactment of a series of laws to a ruler (Motecuhzoma I) who in fact did not enact them. As Sylvie Peperstraete suggests, the laws we are examining in the present arcticle could be enacted under the rule of Motecuhzoma II Xocoyotzin (1502-1520), who should intentionally be interchanged with his same-name 
predecessor in native historical traditions (PERPERSTRAETE 2007:143). Tenochca could shift the enactment of the laws, an important city-state and empire building action, from the period of Motecuhzoma II's rule, when the city-state of Tenochtitlan and Aztec Empire ceased to exist, to a "more famous" period when they experienced a prosperous development (rule of Motecuhzoma I). In addition, by such retrospective projection of Motecuhzoma's laws, Tenochca, I suppose, also could demonstrate to their Spanish lords, that they had a legal code, along with other conveniences (e.g. a complex state apparatus), and in that sense were "fully civilized" yet in their more remote past.

Peperstraete's hypothesis is surely interesting, but it can not be verified sufficiently. Thus, the current state of knowledge allows to consider the author of the laws studied in the present article to be rather Motecuhzoma I than Motecuhzoma II. On the other hand, it is possible, that sumptuary laws, even if enacted (as other Motecuhzoma's laws) during the reign of Motecuhzoma I, started to be enforced more systematically and rigorously yet under Motecuhzoma II's rule (BERDAN - RIEFF ANAWALT 1997:25), which would have corresponded with the effort of this ruler to reinforce the social hierarchy and especially the status of hereditary nobility (nobles by birth; pipiltin, sing. pilli) at the expense of persons who became quasi-nobles (quauhpipiltin, sing. quauhpilli) by their military achievements and their descendants (TRIGGER 2007:161-162).

\section{The contents and social contexts and functions of Motecuhzoma's laws}

Durán's Historia involves a list of individual Motecuhzoma's laws which resembles a legal code. The total number of Motecuhzoma's laws recorded by Durán is 16 , however, we will see that there existed a few other pre-Hispanic legal customs or laws enacted by unknown legislator (Motecuhzoma I? another ruler(s)?), which seem to have been substantively related to those of Motecuhzoma's.

In the following text I successively quote all laws and comment on them. The quotations of individual laws are taken from Doris Heyden's English edition of Durán's Historia (DURÁN 1994). Contrary to the standard Mexican edition of Durán's Historia (DURÁN 2002), the individual laws of Motecuhzoma's are numbered in Heyden's edition. It makes the list of laws clearer and thus I reproduce it below with the ordinal numbers of individual laws.

I divide Motecuhzoma's laws into three categories: laws related to state organization and ideology (laws number 1, 11, 12, 13 and 16); sumptuary laws (laws number 2-10); and penal laws (laws number 14 and 15). Such categorization of the laws is useful, since it enables to 
point to certain interconnections of certain laws (their contents and contexts). On the other hand, utilizing the categorization below, the original sequence of individual Motecuhzoma's laws as reproduced in Durán's chronicle must be ignored partially (the first category contains laws that are not organized one by another in the source text).

\section{Laws related to state organization and ideology}

"1. The king [i.e. tlatoani] must never appear in public except when the occasion is extremely important and unavoidable“ (DURÁN 1994:208).

This law may be related to the process of state formation in Tenochtitlan, of which the emergence of a tiny ruling class, having the ruler on its top and separating itself systematically from the massess of ordinary people, was an essential part. Besides, the law may be connected to Tenochca complex conception of the office of tlatoani, who as "mother and father" of Tenochca nation, a powerful dreaded king, a guarantee of the provision of public services and a kind of gods' terrestrial representative and speaker, endowed with their supernatural forces, had an exclusive status radically distinguishing him and thus relatively isolating him from his subjects. Let us look at the origins of the ruling class at first.

Although a state can arise in many concrete ways, ${ }^{9}$ I believe, following Bondarenko (2008:19-53), that the traditional model of state formation, coined by Lewis H. Morgan and Friedrich Engels, is the most appropriate to explain the very essence of a social transformation that leads to consolidation of a state organization, be it in Tenochtitlan or elsewhere. The model considers the state formation a transition from a stateless (pre-state) society, fragmented into self-governed lineages, clans, tribes or similar personal units, to a state as a relatively coherent society governed centrally by political, i.e. on personal units and their authorities independent power institutions (state apparatus), and organized territorially, i.e. the state's population is permanently distributed into administrative districts and there directly controlled by the state via its local institutions, subordinated to its central institutions. In other words, in a stateless society the power is exercised toward the members of personal units (lineages and the like) by their own authorities, i.e. towards relatives by

9 On state formation in general see e. g. BONDARENKO 2008:19-53; BONDARENKO 2014:215232; CLAESSEN - SKALNÍK (eds.) 1978; CLAESSEN 2010:3-51; GRININ - KORATAYEV 2012:191-204; GRININ et al. (eds.) 2004; KRADIN 2009:25-51; TRIGGER 2007.

DOI: 10.2478/eas-2018-0012 C University of SS. Cyril and Methodius in Trnava. All rights reserved. 
their relatives, while in a state the power is exercised towards the residents of territorial units (administrative districts) by state's (not individual personal units') representatives unrelated by personal ties to those they "govern". In addition, the representatives of the state would become a tiny endogamic ruling class, isolated from the masses of ordinary people (JOHNSON - EARLE 2000:304). The members of the ruling class have an exclusive right to exercise the state (political) power (or at least its major part), although not on their own, but on behalf of the state, i.e. the ruler (monarch), who was the symbolical embodiment of the state in many historical contexts including Tenochtitlan. The state/ruler controls the persons who exercise the political power, however the extent of such control is variable in concrete cases.

The emergence of a ruling class in Tenochtitlan was due to several factors. In Tenochtitlan, from its founding (ca. 1325 AD) on an island of lake Texcoco (central part of the Mexican Valley) to its liberation from Tepanec rule in late 1420s (Tenochtitlan, supported mainly by Texcoco and Tlacopan, conquered the Tepanec Empire's capital Azcapotzalco), existed a type of stateless society which I have described elsewhere and classified there as chiefdom (VYŠNÝ 2012:24ff.). The basic unit of that society was calpulli (plur. calpultin). It was a landowning and thus sedentarized group of a certain number of extended families/households and was self-governing, having a representative (calpulec) who with a few dignitaries formed a council of elders (calpulhuehuetque) as an administrative body. Although having remained stateless prior the liberation from Tepanec rule, the then society of Tenochtitlan experienced some changes which gradually instigated her transformation to the state. Among these changes were: the emergence of the office of tlatoani in the 1370s, to whom all city's inhabitants/calpultin became subjects (i.e. the centralization of power in Tenochtitlan as an important prerequisite of state formation began); and the emergence of an elite (pipiltin, sing. pilli), the posterior ruling class of the Tenochca city-state, whose members were both closer and more distant relatives of Tenochtitlan rulers, as well as commoners with greater military merits and their descendants, called quauhpipiltin ("eagle nobles").

Beside a small circle of pipiltin ${ }^{10}$ there were masses of ordinary people called macehualtin (sing. macehualli). In the pre-state period of Tenochtitlan internal sociopolitical development pipiltin (at least sometimes) participated on administrative, diplomatic, military and cultic activities of tlatoque, but were not yet a ruling class in proper sense, which would arise after

10 It is assumed that ca. 25.000 people lived in Tenochtitlan on the eve of the liberation war waged against Tepanec Azcapotzalco. Ca. $6 \%$ of these people could belong to pipiltin (LEÓN-PORTILLA 2003:254-255). 
the liberation of Tenochtitlan from Tepanec rule. By a ruling class in proper sense I mean, in context of Tenochtitlan history, a privileged group of people who held both central and local offices within the state apparatus and exercised the state power (they administered the city, collected tributes, resolved the conflicts of Tenochtitlan inhabitants, prosecuted and punished criminals, organized cultic ceremonies and performed religious rituals, commanded the Tenochca soldiers when on battlefield and the like), using physical enforcement, institutionalized administrative mechanisms, legal rules and sufficient economic resources, and resting upon an ideology that legitimized their actions. How such a ruling class emerged in Tenochtitlan?

The first step to create the Tenochca ruling class in proper sense should have a curious form of a "social contract" that might conclude pipiltin and macehualtin before the war against Azcapotzalco started. According to some sources (e.g. CLAVIJERO 2003:136; DURÁN 2002, I:126) macehualtin were reluctant to take part in the war that should liberate Tenochtitlan. Pipiltin, who, on the contrary, supported the war, made an agreement with macehualtin in order to carry it out. It was agreed that if Tenochtitlan would be defeated, macehualtin could kill and even consume pipiltin, but if Tenochtitlan would conquest Azcapotzalco, macehualtin would accept pipiltin as a privileged ruling class and would serve them in various ways (they would cultivate pipiltin fields, pay tributes to tlatoani and pipiltin, participate in military campaigns organized by tlatoani and pipiltin and the like). After the victory of Tenochtitlan a public assembly of macehualtin should confirm their commitment and take decision to start its fulfillment (DURÁN 2002, I:129).

It is obvious that the consolidation of ruling class in Tenochtitlan can not be reduced on the conclusion of a "social contract", the more it can not be verified. ${ }^{11}$ Thus, other historical circumstances, which are much more credible, are to be taken into consideration when the emergence of Tenochca ruling class is explored.

The upper social status and various privileges of pipiltin resulted from their separation from macehualtin, as well as their wealth and political power. Besides, they had great social

11 The founding of the Tenochca state by conclusion of a "social contract", mentioned in Durán's chronicle and other sources derived from the Crónica $X$ [Chronicle $X$ ], may be due to possible influence of the authors of these sources by the scholastic political philosophy, which operated since the $13^{\text {th }}$ century with a certain kind of social contract theory (RECASENS SICHES 2003), also processed by Spanish (Salamancan) $16^{\text {th }}$ century second scholastics (e.g. Francisco de Vitoria). On the other hand, the contract concluded by pipiltin and macehualtin could be a result of the manipulation/fabrication of Tenochca historical tradition that occurred during Itzcoatl's reign and was in benefit of tlatoque and pipiltin and their political and economical interests. 
prestige, since they (along with tlatoani) were ensuring the fulfillment of Tenochtitlan's vitally important supernatural mission to maintain a proper everyday "course" and thus the very existence of the world (cosmos). The mission, as it is well known, rested in regular "nourishing" of the gods in order they would constantly be able to perform their supernatural actions which maintained the world's existence and "course". Gods were "nourished" by supernatural energies released mainly from ritually sacrificed humans.

According to Friedrich Katz pipiltin evolved to a ruling class once they definitively had abandoned their calpultin, as well as farming, the prevalent occupation of ordinary people (macehualtin) living in calpultin, and subsequently could become full-time representatives of the state/tlatoani (administrative functionaries, judges, priests, military commanders and the like) and exercise the state power continously and effectively. After pipiltin left calpultin, their personal ties to calpultin members, i.e. to their closer or more distant relatives and neighbours, weakened and finally disappeared. Thus emerged a gulf between "those, who govern" (= pipiltin) and "those, who are governed" (= macehualtin), which is a phenomenon typically connected with the state formation process (KATZ 1956:110).

Katz has stated that pipiltin who had left their calpultin lived (with their families) in tlatoani's palace, where all highest (central) state authorities resided, or on conquered territories where they served as administrative functionaries (KATZ 1956:110). This is true, but there were also pipiltin who never moved away from their calpultin, in which they lived in their palaces (PAREDES GUDIÑO 1986:251). There were about 12 palaces of pipiltin in Tenochtitlan. These palaces, along with estates attached to them (both inside and outside of Tenochtitlan), worked by local macehualtin, and became relatively autonomous socioeconomical units (ROVIRA MORGADO 2011:75-85). Thus, the separation of pipiltin from macehualtin was no physical isolation of the former from the latter to some extent, but rather resulted from a considerable difference of their life-styles: pipiltin distinguished from macehualtin by living in palaces (see also the eighth Motecuhzoma's law below), great wealth, they publicly displayed, non-productive nature of activities, they performed, and the like.

The economic situation of pipiltin was favourable. They were supported by the state, being its representatives. They theoretically could not acquire land in Tenochtitlan, for it was owned by calpultin and used by their members only who pipiltin ceased to be (ZORITA 1963:30), however, in practice they very probably captured themselves some part of calpultin land (REYES GARCÍA 1996:33) and/or were granted parts of such land by tlatoani as recompensation of their participation on state administration. In addition, pipiltin were 
gaining lands on conquered territories (DURÁN 2002, I:129-131 et passim). ${ }^{12}$ Pipiltin were also owners of various prestigious moveable objects, what I will examine later.

The monopoly of pipiltin (including quauhpipiltin) on political power resulted from the way the state functionaries were recruited: the highest dignitaries of the Tenochca city-state, acting in the spheres of administration, judiciary, military and cult, could be only the closest (male) relatives of tlatoque (so-called tlazopipiltin; sing. tlazopilli); other state officials, both central and local, generally called tetecuhtin (sing. tecuhtli), could be pipiltin as well as macehualtin on condition they (both pipiltin and macehualtin) had greater military merits (macehualtin with merits became quauhpipiltin whose social status was hereditary and higher than that of macehualtin, but inferior to that of pipiltin by birth). However, to achieve greater military merits and thus become a state functionary was only possible for a smaller part of macehualtin, since the majority of them, contrary to pipiltin, should dedicate themselves to subsistence activities and could not take part in military campaigns regularly. In addition, the highest (central) offices were not accessible to quauhpipiltin (LÓPEZ AUSTIN 1961; VYŠNÝ 2012).

Tenochtitlan state apparatus, dominated by pipiltin and quauhpipiltin, was centralized and complex. It consisted of central administrative, judicial, military and cultic institutions, residing in tlatoani's palace, and of local state officials, who resided in all calpultin of Tenochtitlan and administered them, however, not on their own completely, but cooperating with their councils of elders (ALCÁNTARA GALLEGOS 2004:167-198; LÓPEZ AUSTIN 1961; VYŠNÝ 2012).

Considering 1. the central (i.e. the most important) state institutions resided in tlatoani's palace, 2. tlatoani, the head of the entire city-state and at the same time the major exponent of pipiltin, should leave the palace and show himself publicly only exceptionally (in principle only when attending cultic ceremonies or on battlefield), 3. the state functionaries recruited mostly from pipiltin and only to a limited extent from former macehualtin (i.e. from quauhpipiltin), and 4. macehualtin were prohibited, under the death penalty, from entering

12 The lands of pipiltin were called pillalli or tecpillalli. Some scholars have concluded that pillalli lands were private property of pipiltin (e.g. KATZ 1956:35ff.), while others have asserted that state/tlatoani owned all these lands and pipiltin possessed them (their parts, respectively) only for a time period they held state offices, which could be life-long at the most (i.e. pillalli lands were not hereditary) (e.g. CARRASCO 1978:24-29). According to the current state of knowledge pillalli lands were owned collectively by members of extended pipiltin families (e.g. KALYUTA 2008), even if private property of these lands could also exist to limited extent (LOCKHART 1992:153-155). 
tlatoani's palace or at least those palace rooms where state institutions dominated by pipiltin exercised their powers (see the eleventh Motecuhzoma's law below), it is possible to conclude that in Tenochtitlan a systematic separation of the ruling class from "the governed" occurred. Such separation prevented inevitably the macehualtin from a participation on the exercise of political power, now concentrated in the hands of pipiltin and quauhpipiltin on both central and local levels and exercised on behalf of tlatoani.

On the other hand, the separation of tlatoani and pipiltin from macehualtin, as well as the monopolisation of political power and acquisition of great wealth and privileges by the former, was at odds with Tenochca state ideology which viewed the ruling class and ordinary people as two unequal, but essential and complementary parts of the society who should peacefully coexist, provide certain services to each other and collaborate in order to fulfill properly the vitaly important supernatural mission (KOVÁČ 2002:210; TRIGGER 2007:490-494). Theoretically, "those who govern" and "those who are governed" were, similarly as in other Claessen's and Skalník's world "early states“ or Trigger's world "early civilizations", ${ }^{13}$ interdependent and their mutual relations were dominated by a principle of asymetric reciprocity (i.e. a reciprocity which was advantageous for both the ruling class and the ordinary people, but for the former to a greater extent), however, this ideal differed considerably from actual life of Tenochtitlan macehualtin who had in their hands but minimal political power, were significantly poorer than pipiltin, lacked their privileges and the like. Among the strategies to overcome or rather to obscure the gulf existing between the ruling class and the masses of ordinary people was, similarly as in other Mesoamerican states (CHASE - CHASE - SMITH 2009:175-182), a paternalistic conception of political power. 
Tlatoani, the major exponent of the ruling class, was considered, for example, inan, ita altepetl, i.e. mother and father of the city-state (Tenochtitlan and its inhabitants), ${ }^{14}$ while macehualtin were referred to as a kind of less perfect persons (as compared to pipiltin), or even as children, who were not fully capable to take care of themselves, and therefore needed to be guided and protected by more perfect persons, tlatoani and pipiltin (SULLIVAN 1980:227). Thus, tlatoani, being not only a ruler, but also "mother and father" of his subjects, had a quasi-familiar relation to them, which symbolically substituted the personal ties of the ruling class and ordinary people, existing before the emergence of social stratification and state organization, and at the same time could make it easier for tlatoani's subjects to accept his rule, since they were used to obeying the (male) heads of the families they lived in, whose position tlatoani so to say imitated, when he became "the mother and father" of Tenochca. ${ }^{15}$

Tlatoani's but extraordinary presence in Tenochtitlan public life can be explained by nonexistence of personal/familiar ties, and thus a natural solidarity, of the ruling class and "the governed". Yet the absence of such ties was disguised by tlatoani's assuming of the role of Tenochca nation's "mother and father", which established a quasi-familiar relation between tlatoani and his subjects. Paradoxically, that role could lead to limiting of physical contact between tlatoani and his "children" (subjects), in order they get an impression their ruler was an exceptional and even mysterious personality whom they could see, listen to or eventually talk to but rarely. Thus, when it happened, they could consider it a very special and important

14 According to the tenth book of Bernardino de Sahagún's Florentine Codex (SAHAGUN 1974:15), a principal source on pre-Hispanic Nahuas and especially on Tenochtitlan, Tenochca should view their ruler, for example, as follows: "The ruler [is] a shelter - fierce, revered, famous, esteemed; well reputed, renowned. The good ruler [is] a protector; one who carries [his subjects] in his arms, who units them, who brings them together. He rules, takes responsibilities, assumes burdens. He carries [his subjects] in his cape; he bears them in his arms. He governs; he is obeyed. [To him] as shelter, as refuge, there is recourse. He serves as proxy, as substitute. The bad ruler [is] a wild beast, a demon of the air, a demon, an ocelot, a wolf - infamous, deserving of being left alone, avoided, detested as a respecter of nothing, savage, revolting. He terrifies with his gaze; he makes the earth rumble; he implants, he spreads fear. He is wished dead."

15 On fictitious, but generally respected quasi-familiar relation between the ruler/ruling class and "the governed“ see BONDARENKO 2008:26-30. 
event in their lives and could want it was repeated, which in turn reinforced their loyalty to tlatoani.

The distinctness and relative separation of tlatoani from his subjects was also due to a fear from tlatoani, spread by tlatoani's and other state authorities' public speeches (van ZANTWIJK 1980:71-87) and actions in public (e.g. brutal executions of criminals).

The last circumstance that distinguished tlatoani from his subjects was his unique political and religious status, briefly described in the following text.

The office of tlatoani experienced considerable changes during the reigns of Itzcoatl and Motecuhzoma I. After the succesfull liberation war waged against Tepanecs, Itzcoatl, now ruler of a sovereign city-state, formed a political, military and economic alliance with Texcoco and Tlacopan, known as Triple Alliance (Excan tlatolayan in nahuatl), which had succesively created a vast empire. Already during his reign, the Triple Alliance gained power superiority in the Mexican Valley, which later became the core zone of the Aztec Empire. At the same time, there was also significant progress of state formation in Tenochtitlan, as a ruling class emerged, an apparatus for both central and local state administration (including administration of justice) was created, and a state ideology was formulated, that legitimized the existence, social order, as well as the imperial ambitions of Tenochtlitlan.

Motecuhzoma I continued the military expansion, whereby extended the empire beyond the Mexican Valley. The appropriation of great wealth constantly flowing from the conquered territories to Triple Alliance cities by their tlatoque and pipiltin deepened the hitherto moderate economical and political differences between macehualtin and pipiltin and contributed to a considerable inequality of both social classes that enshrined, inter alia, the Motecuhzoma's laws (VYŠNÝ 2012:42ff.).

The just mentioned developments also instigated a transformation of tlatoani's office. Tlatoani became a sovereign monarch with universal competence (he was the executive head of the entire state apparatus, the highest judge, military commander and priest, a legislator and the like). In addition, the actual power of Tenochtitlan tlatoque was increasing during the reign of Itzcoatl's successors, mainly that of Ahuitzotl (ruled 1486-1502) and even more that of Motecuhzoma II Xocoyotzin (ruled 1502-1520) (VYŠNÝ 2012:64ff.). On the other hand, at least in the plane of Tenochca state ideology, none of Tenochtitlan tlatoque can completely be considered a "despot" in the sense of Michael Mann's theory of despotic 
power, as distinguished by him from the so-called infrastructural power (MANN 1986, 2008).

According to Mann, both despotic and infrastructural (public) powers are centralized and exercised by state apparatus evenly within the entire state territory, but the former power is exercised "over" a society ("the governed"), while the latter one "through" a society. A government (i.e. a ruler and a ruling class or a state apparatus, respectively) exercising the despotic power unidirectionally imposes its will on a state population, which basically can not participate in formulation and execution of that will. A government exercising the infrastructural power relies on mutually advantageous cooperation with "the governed" "the governed" support the government by, for example, tax payments which is compensated by important services provided to them by the government (e.g. military defense, administration of justice, redistribution of wealth, making of religious rituals, etc.), which is the only institution capable to provide such services effectively and virtually for all citizens. In other words, the infrastructural power, contrary to the despotic power, is exercised, to a certain greater extent, in favor of "the governed", who thus accept it a lot more than the despotic power. On the other hand, in practice any political power is both despotic and infrastructural, however, a power can be more despotic and less infrastructural or less despotic and more infrastructural (MANN 1986; 2008).

In my opinion, the infrastructural dimension of the power of tlatoani (and the ruling class/state apparatus) prevailed over its despotic dimension. It resulted from the complexity of administrative, judicial, economical, military and cultic functions which the state apparatus of Tenochtitlan, headed by tlatoani, daily fulfilled in favor of broad population, i.e. pipiltin and macehualtin alike. For example, tlatoani used to supply macehualtin who were attending public works, became orphans or widows losing their breadwinner in war or became war invalids, had bad harvest and the like with food and dress (KATZ 1956:95-103). In addition, beside various practical services which tlatoani/state apparatus provided to population, there was also the cult which performance, determining the persistence of the world, was seen as tlatoani's primary obligation by his subjects, as well as the main reason 
because of which he was given the political power by the highest civil and military elites of the state which elected him tlatoani ${ }^{16}$ (BRODA 1978:221-255; SAHAGÚN 2001, II:453ff.)

Tlatoani's political power was surely strengthened by his religious status. Tlatoani was not considered a god, but a person endowed by certain gods with certain vital supernatural forces (these forces can be remotely compared to Western concept of a soul) to an extent that was significantly higher than the extent all other people were endowed by them (BRUMFIEL 2000:134). Based on the presence of these forces in his body, tlatoani had a very close relation to gods, along with the possibility to communicate with them, which made him a kind of gods' terrestrial representative and speaker and an executor of their will. This may seem a way to legitimize the eventual willfulness of tlatoani, however, during the ceremonies of new-elect tlatoani's inauguration a public speech was delivered which explicitly pointed out tlatoani's duty to use the supernatural forces he had gained to optimize his government and in favor of his subjects (SAHAGÚN 2001, II:453ff.).

It was believed that all tlatoani's power had a divine origin (LÓPEZ AUSTIN 1961:87). Although tlatoani appeared as the earthly representative of Tezcatlipoca, Huitzilopochtli and possibly some other gods, his power came from the fire god Huehueteotl Xiuhtecuhtli, the manifestation of the supreme god Ometeotl, who had created Tezcatlipoca and the other "younger" gods who, in turn, created the age/world (nahui ollin) in which Tenochca and other Mesoamericans (according to their belief) lived. This idea should be an important source of legitimacy of tlatoani's power, as its origin attributed to the highest of the gods (SULLIVAN 1980:233; TRIGGER 2007:83).

In addition, tlatoani was also a representative of god Quetzalcoatl, who was ruler of a celestial city, which was considered a mythical original homeland of the humankind by Mesoamericans living in postclassic period (ca. 900/1000-1520 AD). That city had several names, for example Nahuas called it "Tollan", Mayas "Zuyác" etc. As at some point groups of people left Tollan, i.e. celestial (divine) world, for human world, i.e. Mesoamerica, the god Quetzalcoatl created from himself certain gods subordinated to him, which became central gods of these groups ${ }^{17}$ and founded for them cities throughout Mesoamerica, including Tenochtitlan. The cities were terrestrial copies of Tollan and were governed by Quetzalcoatl, even if not directly, but through gods which founded them and were

16 It is not completely clear which concrete elites of Tenochtitlan were the electors of tlatoani.

17 The central god of Tenochca/Mexica was Huitzilopochtli.

DOI: 10.2478/eas-2018-0012 C University of SS. Cyril and Methodius in Trnava. All rights reserved. 
represented by cities' human monarchs who came from cities' royal dynasties founded by these gods (LÓPEZ AUSTIN - LÓPEZ LUJÁN 1999; LÓPEZ AUSTIN - LÓPEZ LUJÁN 2014:281ff).

Before we turn to other Motecuhzoma's laws concerning Tenochca state organization and ideology let us conclude that there were various factors clearly distinguishing and the same time separating tlatoani and pipiltin from macehualtin. Such separation was surely advantageous for the former, since it enabled them to concentrate great political, economical and ideological power in their hands and exercise it with but minimal participation of macehualtin. No suprise that in such a situation the isolation of the ruler, the major exponent of the ruling class, from masses of ordinary people, was legally enshrined. On other hand, the political power was more infrastructural than despotic in Tenochtitlan and thus exercised to some extent in favor of macehualtin.

"11. In the royal palace there are to be diverse rooms where different classes of people are to be received, and under pain of death no one is to enter that of the great lords or to mix with those men [unless of that class himself]. Each one is to go to the chambers of his peers. A tribunal is to be set up to resolve complaints, disputes, and possible damage caused." (DURÁN 1994:210).

It will be useful to describe briefly the state institutions residing in tlatoani's palace, before we comment on this law.

In tlatoani's palace resided the central organs of the city-state which can be devided into monocratic and collective ones.

To the monocratic organs (i.e. individual dignitaries) belonged: tlatoani and a certain number of tlazopipiltin, from which the most important were: cihuacoatl, in principle a co-ruler of tlatoani, but not completely equal to him, and four tecutlatoque (two of them were the highest military commanders and the remaining two the highest judges), only of which the next tlatoani could be elected (LÓPEZ AUSTIN 1961:87ff.).

Collective organs residing in the palace were:

a. courts:

a1. inferior tribunal (teccalli) with jurisdiction over civil and minor criminal cases concerning macehualtin;

a2. superior tribunal (tlacxitlan) with jurisdiction over macehualtin who committed serious crimes, as well as over civil and criminal cases concerning pipiltin; 
a3. tribunal called tecpilcalli with jurisdiction over delinquents pertaining to tlazopipiltin and other pipiltin living in tlatoani's palace and the highest military dignitaries;

a4. tribunal of cihuacoatl which was the supreme court and had universal jurisdiction. It was chaired by cihuacoatl or, once every twelve days in principle, by tlatoani;

b. the office of achcacauhtin, who maintained the public order during public religious festivals, had detained the delinquents before their trials began and made executions;

c. the council of the highest military dignitaries (commanders, respectively), residing in the room called tequihuacacalli or quauhcalli;

d. the assembly of tribute collectors (calpixque) who were gathering in a room called calpixcalli or texancalli. On the assembly, the tribute collectors were both given instructions concerning their activities and controlled wether they fulfilled their obligations properly;

e. the assembly of lesser military dignitaries (tiachcahuan, telpuchtlatoque), who were meeting in a room called cuicalli. These dignitaries worked as teachers in public schools (telpochcalli) residing in all calpultin of Tenochtitlan and attending mostly by later pubertal and adolescent macehualtin (SAHAGÚN 2001, II:663-668).

Motecuhzoma's eleventh law fits well into the just described structure of central state organs. Macehualtin were prohibited from entering tlatoani's palace, except for meet the teccalli or tlacxitlan judges who were competent to resolve their cases. The law, on the one hand, reinforced the above discussed separation of "those, who governed" and "the governed", as the latter, unless they had greater military merits (a minor part of macehualtin had such merits), not only could not participate in the exercise of state power, but they even could not get into physical contact with persons exercising that power. On the other hand, the law also reflected the complex character of Tenochca central state organs system, within which a specialization occurred (we can distinguish administrative, judicial and military organs with their respective separated rooms in tlatoani's palace and respective specific powers), as it established: "In the royal palace there are to be diverse rooms where different classes of people are to be received... Each one is to go to the chambers of his peers." (DURÁN 1994:210).

The jurisdiction of palace courts seems to have been based, according to the law we are now examining, on the principle iudicium parium, i.e. any person may be tried only by persons having the same social status. However, macehualtin, be it at teccalli, tlacxitlan, or tribunal of cihuacoatl, were judged by persons who were not socially equal to them, i.e. they had a higher social status. Namely, to become a judge (at least a palace, i.e. a higher judge), one 
should meet strict requirements, beside to have greater military merits, to be pilli or quauhpilli, graduate from an elite school (calmecac), be wealthy, not to consume pulque (an alcoholical beverage) etc. (SAHAGÚN 2001, II:672), which was imposible for macehualtin.

The eleventh law is substantively connected with the twelfth law which focuses on the judiciary.

"12. An order of judges is to be established, beginning with the judges of the supreme council. After these would come regular court judges, municipal judges, district officials, constables, and council-men, although none of them may give the death sentence without notifying the king. Only the sovereign can sentence someone to death or pardon him. (Even in this they wished to act like gods.)" (DURÁN 1994:210). ${ }^{18}$

Motecuhzoma's twelfth law enshrines a complex system of Tenochtitlan courts which was centralized and hierarchic. There are some terminological and factual uncertainties concerning this system in the sources, which, however, López Austin has largely resolved (LÓPEZ AUSTIN 1961: 97ff.).

The central (palace) courts were mentioned above. Here should be added that "the judges of the supreme courts" $" 19$ were either the judges of the tribunal of cihuacoatl or members of tlatocan, a supreme council of Tenochtitlan with, inter alia, a judicial power, which members were tlazopipiltin and other high dignitaries, both military and civil (LÓPEZ AUSTIN 1961:94-97). Considering that tlatocan was no permanent organ, i.e. its members gathered but occassionally (irregulary) (LÓPEZ AUSTIN 1961:94-97), I believe that "the judges of the supreme courts" were rather the members of the tribunal of cihuacoatl who in principle judged on a daily basis.

The "regular court judges" and "municipal judges" 20 were probably the judges of tlacxitlan (the former) and teccalli (the latter). The court tecpilcalli seems no to be mentioned in

18 In the Mexican edition of Durán's Historia the first sentence of the twelfth law partially differs from Heyden's edition. Cf. "ordenose que uviese justicias á quien acudiesen EN los pleitos y quejas y agrauios. Despues de los oydores, que eran del supremo consejo..." (DURÁN 2002:266).

19 In the Mexican edition of Durán's Historia these judges are called "oydores del supremo consejo" (DURÁN 2002:266).

20 In the Mexican edition of Durán's Historia these judges are called "alcaldes de corte" and "alcaldes ordinarios" (DURÁN 2002:266).

DOI: 10.2478/eas-2018-0012 C University of SS. Cyril and Methodius in Trnava. All rights reserved. 
Motecuhzoma's twelfth law, from which results it was established somewhere later (not during Motecuhzoma I's rule).

On a local level, i.e. in individual calpultin, the judicial power held "district officials", "constables" and "council-men". ${ }^{21}$ District officials were administrators of individual calpultin (tetecuhtin, sing. tecuhtli), appointed by tlatoani, who exercised their judicial power (along with their certain administrative powers) with aid of an auxiliary personnel (= constables) and calpultin councils of elders (ALCÁNTARA GALLEGOS 2004:187ff.). According to López Austin, teccalli was not a palace court, but a calpulli court chaired by tecuhtli who minor cases judged on his own and major cases ceded to tlacxitlan judges (LÓPEZ AUSTIN 1961:97-99). This is quite possible, however other scholars consider teccalli a palace court.

The following two laws concern Tenochtitlan state ideology. The law number 13 establishes the compulsory school attendance which enabled the Tenochca state to acquaint, as well as to identify virtually all population with the axiological and normative foundations of Tenochtitlan social order and especially its supernatural mission, the central axis of the state ideology and religion. The law number 16 enshrines a privileged status of priests whose spectacular rituals were a complex means through which the ideological/religious doctrines were actualized and the mission carried out.

"13. All the barrios [calpultin] will possess schools or monasteries for young men where they will learn religion and correct comportment. They are to do penance, lead hard lives, live with strict morality, practice for warfare, do physical work, fast, endure disciplinary measures, draw blood from different parts of the body, and keep watch at night. There are to be teachers and old men to correct them and chastise them and lead them in their exercises and take care that they are not idle, do not lose their time. All of these youth must observe chastity in the strictest way, under pain of death." (DURÁN 1994:210).

Minimally in Triple Alliance cities existed the compulsory school attendance. All population and both sexes started, at the age between 12 and 15 years (sometimes perhaps 10 years old),

$21 \quad$ In the Mexican edition of Durán's Historia these judges are called "corregidores", "alguaciles" and "regidores" (DURÁN 2002:266).

DOI: 10.2478/eas-2018-0012 C University of SS. Cyril and Methodius in Trnava. All rights reserved. 
to be educated in a public school, and continued in education until reaching the age of marriage (girls: 15-18 years; boys: 20-22 years) (HINZ 1990:191-192).

The descendants prevalently of pipiltin attended an elite school (calmecac) providing a higher education. The school resided in the sacred precinct in central Tenochtitlan and was administred by priests (tlenamacac, tlamacazqui). Its divine patron was god Quetzalcoatl. Calmecac was a school for boys only. Girls belonging to pipiltin were educated by priestesses in an separate institution, residing in the sacred precinct (HINZ 2002:112-113; LÓPEZ AUSTIN 1961:117ff.).

The descendants of mostly macehualtin attended schools called telpochcalli residing in all calpultin. The schools were consecrated to god Tezcatlipoca and administred by lesser military dignitaries (telpochtlato, tiachcauh). Girls belonging to macehualtin were educated separately from boys by local elder women (HINZ 2002:112-113; LÓPEZ AUSTIN 1961:117ff.)

Tenochtitlan schools have been instrumental in their pupils' general socialization. The didactic programs of calmecac and telpochcalli differed, but both were complex. In calmecac were educated mainly future priests, high officers and judges, while in telpochcalli primarily warriors were trained who later (based on their eventual military merits) could become (lesser) military dignitaries. Pupils of telpochcalli used to attend regularly public works (they constructed or maintained palaces, temples, roads, causeways, canals and the like). Although their education was prevalently a practical one, they also were acquainted with the fundaments of religion. Pupils of calmecac worked physically (usually in the school edifice, not on public works) and were military trained as well, but their education was primarily focused on retorics, etiquette, ethics, law, astrology, whole religious theory and practice, history and the like. They had a lot more specific religious duties (e.g. bloodletting), were subject to a stricter discipline (e.g. absolute sexual abstinence) and were punished more rigorously than pupils of telpochcalli. In addition, they lived isolated from their families in 
their school, while pupils of telpochcalli were visiting their parents at times in order, for example, to help them with their field works (HINZ 2002:112-113).

"16. Great privileges and exemptions are to be given those who dedicate themselves to religion, to the temples and the gods. Priests will be awarded great distinction, reverence, and authority." (DURÁN 1994:210).

The priests, generally called teopixque (sing. teopixqui), were professional managers of the city-state cult life and performers of cult rituals. Their activities, essentially atributing to successfull fulfillment of Tenochtitlan's mission, were highly appreciated by the state/tlatoani. No suprise a large organization of priests as a relatively autonomous part of the state apparatus emerged. The organization was hierarchical and had its own economic ressources, including land (KATZ 1989:253-256). On the other hand, priests were subject to a strict discipline. For instance, a priest who did not maintain the celibacy had to be executed, according to a law, mentioned in manuscripts Historia de los mexicanos por sus pinturas [History of the Mexicans as Told by Their Paintings] and Éstas son leyes que tenian los indios de la Nueva España, Anáhuac o México [These are the laws of Indians of New Spain, Anáhuac or México] ${ }^{22}$ (Las literaturas indígenas 1985: 716, 751). Priests also had many religious duties, as various complicated rituals, including spectacular public ceremonies, should be made in each 20-day "month" of the year, having 18 "months" (veintenas) plus five extra days (GRAULICH 1999). The proper fulfillment of these duties was systematically controlled by the priests themselves who monitored each other and pointed to other priests' delicts. Priestly delinquents were physically punished by other priests and/or could loose their priestly offices, unless they paid a fine (they gave e.g. a certain amount of textiles that were a kind of money) to priests who denounced them, which probably was possible only when the delicts they had committed were not serious or repeated (SAHAGÚN 2001, I:119-120, 164ff.).

Let us conclude here that the Motecuhzoma I's laws examined above reflect a great complexity of Tenochca state organization. Such complexity was also due to various penal laws (they were not part of Motecuhzoma I's legislation), which established, inter alia, that state officers and judges, as well as military dignitaries were responsible for their activities and conduct and thus neglect of duties, disobedience to orders and various delicts considered serious crimes, e.g. abuse of authority, bribery or alcoholism, of these persons lead to loss of their posts and a rigorous punishment, in certain cases even to their execution (VYŠNÝ 2012:182ff.). 


\section{Sumptuary laws}

Before I examine concrete Motecuhzoma's sumptuary laws I will briefly summarize the main features of sumptuary legislation and its social functions, as well as point to some Tenochca empiric correlates of these features and functions.

Sumptuary legislation is a phenomenon that can be find world-wide (in various time periods). Simply put, such legislation regulates the acquisition, ownership and public display of prestige objects, also called "prestige goods", both moveable (e.g. dress, jewelry, food, power or military insignia, ritual objects) and immoveable (e.g. palaces). More generally expressed, it regulates who can and who can not perform a luxurious life-style. It has several social functions outlined below, one of which, the most obvious, is deepening and stabilization of social hierarchy: there are people who can not gain the prestige objects, as well as people who can gain such objects (on condition they meet certain criteria), however, some of these people have not access to all or but to less prestigious objects. In other words, it is legally enshrined who can/can not acquire any or concrete prestige objects. The just mentioned function had also Motecuhzoma's sumptuary legislation, as it established (even if not completely clearly) three unequal social classes: a ruling class (tlatoani, tlazopipiltin and pipiltin), macehualtin with military merits who became certain military dignitaries and in principle can be identified with quauhpipiltin, and masses of ordinary macehualtin. We will see below that macehualtin, unless they had certain military merits, could gain no prestige objects, although in practice were acquiring some of them. Macehualtin with military merits could gain prestige objects, theoretically only from tlatoani (the state), but such objects had to be less prestigious than those pipiltin were receiving from tlatoani. Prestige objects of tlazopipiltin (or at least some of them) seem to have been more prestigious than those of pipiltin. Finally, there were special prestige objects which only tlatoani could own.

Thus, at least in theory, prestige objects could be property of only tlatoque, pipiltin and merited warriors/quauhpipiltin. This state of affaires was not only legally enshrined, but also mythically legitimized. According to Crónica Mexicayotl Tenochca, in an early period of their history (before they settled down on a lake island which later would convert itself to the city of Tenochtitlan), were promised by their god Huitzilopochtli that they would successively conquer all other states and make them - as "lords of all the world" - to pay rich tribute, including multiple prestige objects, to Tenochtitlan, the "centre of the world" 
(TEZOZOMOC 1998:23-25). León-Portilla has related Huitzilopochtli's promise with an important Tenocha myth which narrates how Huitzilopochtli defeated and killed his divine siblings (sister Coyolxauhqui a 400 brothers), in order to prevent them from killing their and Huitzilopochtli's mother (goddess Coatlicue), and seized their precious miraculous things, i.e. prestige objects, making them a part of his tonalli, i.e. his "destiny" or supernatural essence (LEÓN-PORTILLA 2003:240-241). Considering the prestige objects owned by tlatoque a pipiltin were referred to as in-tonal ("their destiny") and tlatoque and pipiltin were Huitzilopochtli's terrestrial representatives acting on his behalf(DURÁN 2002, I:111), it may be concluded, that the Tenochca military expansion and prestige goods extraction from the conquered states was an imitation of an archetypal god's deed by his human proteges. Since macehualtin, contrary to tlatoque and pipiltin, were not Huitzilopochtli's representatives, nor were organizing and leading military campaigns, they had no right to gain prestige objects, and this could change only when they achieved certain military merits and only to a limited extent, as clearly results from the fact, that the prestige objects of merited warriors/quauhpipiltin were inferior to those of pipiltin and tlatoque.

To understand sufficiently the above mentioned as well as other social functions of sumptuary legislation it is necessary to render the essence of prestige objects. The prestige objects have certain typical features, usually more features at the same time, which I briefly describe below.

Prestige objects are not only luxurious (rare, precious, very valuable, not for use as, for example, working instruments intended and the like) material things in the economic sense, but also - and this above all - items with specific meta-economic (symbolic) meanings, which they both bear and nonverbally communicate to people who appear in the vicinity of prestige objects' owners. The basic meaning of prestige objects is clear: they are material, and thus well visible, markers of a higher social status of their owners. However, there are yet other, more complex meanings of prestige objects.

Prestige objects often symbolize certain greater personal qualities of their owners (their superior knowledge, abilities and skills), as well as their collectively important deeds, because of which (both qualities and deeds) they were awarded with such objects (PLOURDE 2008). This was also case of Tenochtitlan where a special category of prestige objects, the military insignia, existed. These insignia symbolized certain greater military deeds/merits of their owners who were various military dignitaries. The principal military 
insignia were: a feathered (tlahuiztli) or skirted (ehuatl) warrior suit, a headdress and/or back device, and a shield (BERDAN 2014:262).

Tenochca military insignia seem to have had a great importance. These were prestige objects whose distribution (to warriors with merits) was systematically monopolized by tlatoani, although such monopoly, the same as in case of other prestige objects, was surely not absolute (e.g., some insignia were sold/bought on markets at times) (BERDAN 2014:266-268). In addition, the military insignia could basically be considered the so-called "inalienable wealth", which means, inter alia, that they should be res extra commercium (it was not possible to trade with these objects) and be inheritable (there was a custom to burn these objects with their deceased owners, as the military merits they symbolized were but personal, i.e. not transferable to their owners' heirs). However, as already mentioned, military insignia were not completely res extra commercium and their status as inheritable objects is questionable as well, as sometimes these objects may have been inherited (BERDAN 2014:266-268).

Concrete military insignia symbolized concrete extent of military merits of their owners, which was "measured" by, inter alia, the number of enemies individual Tenochca warriors had captivated on battlefield and transported to Tenochtitlan where the captives were sacrificed to gods. The more people Tenochca warriors captured, the greater were their military merits, the more prestigious were the insignia by which they were rewarded (by tlatoani) and the higher were the military ranks they were given (by tlatoani). To hold civil offices was in principle impossible for both pipiltin and macehualtin unless they had achieved certain military merits/ranks (SAHAGÚN 2001, II:684-687).

The obtaining of military insignia elevated not only the social status and personal prestige of a warrior, but also the extent of his responsibility for the maintenance of the supernatural world (cosmic) order. Namely, to be Tenochca warrior meant to be a person who in longterm and actively, mainly by frequent participating in military campaigns and capturing of enemies, contributed to the fullfilment of Tenochtitlan mission "to nourish" the gods. Thus, the distribution of military insignia by tlatoani was not only rewarding, but it also was supposed to motivate the rewarded warriors to continue in their military activities/captivating enemies in the future, which is in accordance with Tenochca authentic notion of a prestige object as something that so to say ties its owner to his primarily military obligations (BRODA 1977:53). In other words, the obtaining of a prestige object implied a permanent moral duty for its owner to contribute to the maintenance of the world order, which Tenochca, similarly as many other pre-modern world cultures, understood as a positive situation which, however, should both gods and people maintain by ritual actions (people by, even if not only by, human 
sacrifices), in order to prevent it from its decline to a chaos. The duty of Tenochca owners of military insignia to contribute to the maintenance of the world order found its expression mainly in their obligation to take part in military campaigns and, if necesary, readily die in a battle, as Sahagún expressis verbis has put it in his description of military insignia distribution ceremony held in the eleventh "month" ochpaniztli (SAHAGÚN 2001, I:197).

Also holding of civil (administrative, judicial, priestly) offices can symbolize (and confirm) certain prestige objects (power insignia) belonging to officers, who were pipiltin and quauhpipiltin in Tenochtitlan. In this relation, it is worth mentioning that after the Spanish conquest of the Aztec Empire, i.e. in a colonial society, Nahua elites used to ground their superior social status on their ownership of pre-Hispanic or upon pre-Hispanic prototypes produced power insignia (OLKO 2011:455-469).

Further, prestige objects may have religious meanings and be involved in religious practices. In Tenochtitlan it was believed, for example, that prestige objects were sacral entities in which tonalli, a supernatural vital force identified with light and heat (CARRASCO 1998:78, 97, 98, 121) of their owners was concentrated (OLKO 2006:67), or which gave a greater tonalli to their owners (BRUMFIEL 2000:134-137), respectively. Thus, a Tenochca who gained a prestige object, not only reconfirmed or gained a higher social status, but also experienced a progressive, even supernatural change of his body/personality, which acquired a certain new - and superior - quality. Prestige objects also manifested a direct and intensive involvement of their owners into the functioning of the world order, based on a circulation of, inter alia, tonalli (BRUMFIEL 2000:134), to which the owners were contributing, as they were regularly "releasing" tonalli from bodies of (mainly) enemies they captured and sacrificed. Prestige objects were a special reward for this vitaly important activity.

Last but not least, prestige objects may bear ideological meanings which may have a political importance at the same time. This was also in Tenochtitlan case, as many prestige objects were considered to have Toltec origin (SAHAGUN 1979:165-169). Toltec Empire (ca. 9501150 AD) existing in central Mexico was a remote predecessor of the Aztec Empire, glorified by Nahuas and other Mesoamericans as a place where a high civilization emerged and a legitimate imperial rule was established. Tenochtitlan tlatoque as indirect descendants of Toltec rulers claimed to be their political successors and restorers of their sway, in order to reinforce the legitimacy of their own rule and imperial expansion. Thus, the prestige objects of Toltec origin (or produced upon Toltec prototypes) manifested links existing between their owners (tlatoani, elites) and the primary source of legitimate power (Toltec Empire). This function of prestige objects yet had been reinforced by an identification of Toltec capital Tula with the celestial city of Tollan, the seat of Quetzalcoatl, which in turn enabled the Tenochca 
rulers to declare themselves terrestrial deputies of this divine ruler of mankind, who founded - through his alter ego, the god Huitzilopochtli -, among other Mesoamerican cities, also Tenochtitlan (see above). In addition, a doctrine of divine or semidivine origin of tlatoque and pipiltin emerged who - contrary to macehualtin - should be descendants of a ruler of Tollan whom either Quetzalcoatl himself or his human deputy (priest) endowed with his divine force was (TRIGGER 2007:145).

From the brief characteristics of prestige objects results that in a society such as, for example, the Tenochca one was, a considerable demand for prestige objects should exist. The members of Tenochca society, both pipiltin and macehualtin, could not occupy certain higher positions in the sociopolitical hierarchy, nor could elevate from their positions to higher ones, unless they had gained prestige objects which materially manifested and symbolically confirmed, as well as nonverbally, but understandably for society members communicated a superior social status of their owners in the public.

It can be the case, that the demand for prestige objects is satisfying exclusively the ruler/state and this, moreover, in accordance with sumptuary laws he himself has enacted, which gives him an opportunity to manage and control the distribution of prestige objects and thus the titles, offices, military ranks, palaces, estates and the like, which acquirement (from the state/ruler) the obtaining of respective prestige objects (from the state/ruler) symbolizes and confirms (BOURDIEU 1998:69ff.). It follows that there may be another important function of sumptuary legislation which can be defined as subordination and creation of loyalty and obedience of the recipients of prestige objects to the state/ruler, the only distributor of prestige objects. In Tenochtitlan, however, tlatoani's monopoly on distribution of prestige objects was not absolute. Besides the providing of persons meeting respective criteria with prestige objects by tlatoani, who was gaining these objects as a war booty, tribute paid by provinces, gifts or from artisans working exclusively for him, individuals could obtain multiple (but surely not all) prestige objects on their own (to some extent) (BERDAN 2014:271ff.), however, the non-elite owners of prestige objects may have been prohibited from displaying them publicly (BERDAN 2014:274). Thus, some prestige objects were occasionally bought on markets, inherited, gained as a war booty, privately produced, received as gifts, privately provided/sacrificed to idols representing gods and the like. The fact that there existed non-state production of some prestige objects and trade with such objects is to be associated with an internationalization of middle to late postclassic (ca. 12001520 AD) Mesoamerican economy (e.g. long-distance trade), as well as with her commercionalization (e.g. the rise of markets) and especially the commercionalization of certain prestige objects (BERDAN - SMITH 2004). In other words, partial circumvention or moderate application, respectively, of Motecuhzoma's sumptuary laws, was present in 
Tenochtitlan and the Aztec Empire. This phenomenon, probably reduced yet during the rule of Motecuhzoma II, also may have been in accordance with a typical feature of legislation existing in Claessen's and Skalník's early states - a legislation, i.e. a law enacted by the ruler, should not essentially differ from a customary, i.e. a traditional law, otherwise the early state ordinary population, well self-identified with the traditional law and long-term paying respect and obedience to it, would very probably be strongly reluctant to abide the legislation, the more it used to favorize (to some extent) a tiny ruling class at the expense of ordinary people (CLAESSEN 1998). Having been Motecuhzoma's sumptuary laws rather a new law, their acceptance by masses of macehualtin, who were disadvantaged by it, could be low, and thus the ruling class, at most $10 \%$ of the society (VYŠNÝ 2012:65), could prefer a moderate application of sumptuary laws in order to avoid a protest or even a rebellion of macehualtin. In addition, there was one exemption from the sumptuary laws which concerned the professional merchants (pochteca, sing. pochtecatl). Merchants, to an uknown, but rather greater extent, could gain prestige objects on their own, particularly buying them on markets throughout, as well as beyond the Aztec Empire, and display them publicly (cf. SAHAGÚN 2001, II:706ff.).

On the other hand, whatever limited the actual enforcement of sumptuary laws in daily life of Tenochca could be, it is indisputable that the legal regulation of acquisition, ownership and public display of prestige objects as items with multiple deep meanings outlined above, had to have a certain greater social significance (see OLKO 2014). There surely existed a permanent demand of Tenochtitlan pipiltin, as well as macehualtin with military merits for prestige objects, and such demand existed also among provincial rulers, elites and non-noble warriors with merits, whom also tlatoani of Tenochtitlan (occasionally) provisioned with prestige objects, establishing thus between him and the recipients of prestige objects firm relations, considerably contributing to the integration of the otherwise strongly decentralized Aztec Empire (BREUER 1988:58-59). Such relations were both political (they emphatisized the subordination of provincial rulers to tlatoani of Tenochtitlan) and personal (provincial rulers were a kind of partners or clients of Tenochtitlan tlatoani, having the former and the latter some common political, economic and religious interests). At the same time they were mutual, as, for example, provincial rulers the prestige goods were not only receiving from tlatoani of Tenochtitlan, but also they were donating some to him. In other words, there were complex links between Tenochca and provincial rulers and elites, maintained, inter alia, by mutual giving of prestige goods. Upon such links was based a mode of metropolitan and 
provincial rulers' and elites' international cooperative coexistence, known as "elite culture" (SMITH 2008:11-12).

Mutual relations between a distributor (ruler) and recipients of prestige objects, which enabled the former to control the latter, his subjects, "from above" (as a supreme power authority) and centrally, were also crucial inside Tenochtitlan and other Nahua city-states. As some scholars assert (e.g. LOCKHART 1992; ROVIRA MORGADO 2014) the structure of Tenochca society, as well as broader Nahua society, was not only hierarchical, but also and this possibly to a major extent - heterarchical. ${ }^{23}$ This means that in Tenochtitlan and elsewhere two opposed tendencies of sociopolitical development co-occurred. One tendency was to maintain (or to reinforce) the all-society hierarchy/stratification with tlatoani and a tiny ruling class on its top and to concentrate the political power in the hands of tlatoani in order he could exercise it on both central and local levels, to which the emergence of a centralized pyramidal state apparatus headed by tlatoani was instrumental. Another tendency, existing among both pipiltin and macehualtin, was to evade the power of the state/tlatoani to the most possible extent and pursue they own interests whose presence in Tenochtitlan may confirm, for example, a transformation of pipiltin and macehualtin landpossessing households (palaces in case of pipiltin, respectively) into relatively closed, autonomous and autarchic residential, familiar and socioeconomic units (ALCÁNTARA GALLEGOS 2004; KALYUTA 2008). As is obvious, the second tendency desintegrated Tenochca society to some extent and weakened the factual power of tlatoani. Thus, the distribution of prestige objects by tlatoani (the state) on condition that their recipients had provided and would further provide certain services to him had to be an important strategy to overcome such situation.

23 Hierarchy is a vertical form of social inequality. It resembles a multilayer pyramid, while all people on a given level have better social position than people on lower level(s) and worse social position than people on higher level(s). The heterarchical social organization is a network whose nodes have more or less the same social position and mutual relations involving cooperation, competition and conflicts. In any complex society can be found both hierarchy and heterarchy, however, the extent to which they occur is variable in concrete cases. 
One more function of sumptuary legislation may be specified. The owners of prestige objects display them, at least occasionally, publicly. In Tenochtitlan they were doing this mainly during frequent religious festivals, whereby they so to say outbragged themselves before people who could not or could only to a limited extent have prestige objects, but who were aware of their great value and who thus gave admiration and recognition, and even become loyal and relatively obedient, to prestige objects' owners. In other words, the public display of prestige objects by their owners, regulated by sumptuary legislation, is a form of conspicuous consumption, i.e. a means by which a higher social status is reconfirmed and political power gained or augmented (TRIGGER 2007:541, 669).

Let us continue with concrete Motecuhzoma's sumptuary laws which were nine.

"2. Only the king may wear a golden diadem in the city, though in war all the great lords and brave captains may wear this (but on no other occasion). These lords and warriors represent the royal person when at war and thus could at that time wear the golden diadem and royal insignia. “ (DURÁN 1994:208).

Besides the royal crown-like diadem (xiuhuitzolli) made of gold and covered with a turquoise mosaic, mentioned in this law, there were multiple prestige objects, for example a blue cape adorned with turquoise (or designed in a turquoise color), turquoise nose plug, lip plug and ear plugs, decorated sandals, certain military insignia, a wowen reed seat used by tlatoani as a throne etc. (BERDAN 2014:151), which were considered royal insignia, i.e. insignia which exclusively tlatoani could have (except for the situation when some high elites represented him on the battlefield).

A deep symbolism concerned the royal diadem, which was especially related to the materials - gold and turquoise - from which the diadem was made. Both materials linked tlatoani to celestial world of gods and to important gods and their supernatural activities, which can be seen already from the etymology of Nahua expression for gold, teocuitlatl, meaning "gods' excrement". Gold connected tlatoani with, for example, Xipe Totec, a divine patron of goldsmiths and god of new (spring) vegetation, fertility, agriculture, as well as war. Since a support of rain, rich harvest, successful military campaign etc. was not only an activity of Xipe Totec, but also a responsibility of tlatoani, who was fulfilling it mainly making respective rituals, it may be observed, that tlatoani had frequently been acting as a terrestrial representant, or even an embodiment, and a collaborator of god. Golden diadem and other royal insignia made from this metal also connected tlatoani with the principal Tenochca god Huitzilopochtli which deputy tlatoani was etc. (BAQUEDANO 2005). 
The Laws of Motecuhzoma Ilhuicamina

The symbolism of turquoise (xihuitl) was also complex. Primarily it linked tlatoani to fire god Xiuhtecuhtli, which was seen as a principal divine source of terrestrial rulers'power (TAUBE 2012:130).

Beside turquoise, there was another stone considered prestige object, the jadeite (chalchihuitl). According to a Tenochca law, macehualli who stole such stone had to die by lapidation, executed in public (on the marketplace) (Las literaturas indigenas 1985:751).

"3. Only the king and the Prime Minister Tlacaelel may wear sandals within the palace. No great chieftain may enter the palace shod, under pain of death. These noblemen are the only ones to be allowed to wear sandals in the city and no one else, also under pain of death, with the exception of men who have performed some great feat in war; because of their valor and courageous deeds they may wear sandals, but these must be common and of low quality. The gilded, adorned ones are to be used only by noblemen." (DURÁN 1994:20).

This law clearly reflects the Tenochca social hierarchy, as well as the opportunity of merited warriors to ascend to a more favorable social position. Sandals could be worn only by pipiltin and warriors with military merits (quauhpipiltin, respectively), however the sandals of the latter had to be a lot simpler than those of pipiltin. On the other hand, both pipiltin and merited warriors had to take their sandals off when they dwelled in royal palace, wherein only tlatoani and the highest dignitary after tlatoani (i.e. cihuacoatl who in times of Motecuhzoma Ilhuicamina was Tlacaellel), could be shod. The supremacy of the ruler and cihuacoatl over pipiltin and merited warriors was thus emphasized. Macehualtin could not be shod, unless they had certain military merits.

The following four laws are substantively interlocked (they regulate the use of prestige dress by tlatoani and social classes). I will quote them one after another and comment them altogether.

"4. Only the king is to wear the fine mantles of cotton brocaded with designs and threads of different colors and adorned with feather-work; these will be worked with gold and embroidered with royal insignia. The king is to decide which type of cloak is to be used by 


\section{The Laws of Motecuhzoma Ilhuicamina}

the royal person and at which times, in order to distinguish him from the rest. " (DURÁN 1994:208-209). ${ }^{24}$

"5. The great lords, who are twelve, may wear special mantles of certain make and design, and the minor lords, according to their valor and accomplishments, may wear other." (DURÁN 1994:209).

"6. The common soldiers are permitted to wear only the simplest type of mantle. They are prohibited from using any special designs that might set them off from the rest. Their breechcloths and waistbands must be in keeping with the simplicity of the mantle. " (DURÁN 1994:209).

"7. The commoners will not be allowed to wear cotton clothing, under pain of death, but can use only garments of maguey fiber. The mantle must just cover the knee and not be worn longer than this. If anyone allows it to reach the ankle, he will be killed unless he has wounds received in war on his legs [then he will be permitted to cover these with the longer length].

(And so it was that when one encountered a man who wore his mantle longer than the law permitted, one immediately looked at his legs. If he had wounds acquired in war he would be left in peace, for in this way he was able to cover those wounds he had been given by being valiant, and if he did not have those wounds he would be killed. People would say, "Since that leg did not flee from the sword, it is just that he be rewarded and honored.")'" (DURÁN 1994:209).

The dress code enshrined in the just quoted sumptuary laws made the Tenochca social hierarchy well visible - the higher social status of a Tenochca male individual was, the more luxurious his mantle. On the top of the hierarchy was tlatoani and after him were: "(twelve) great lords", i.e. tlazopipiltin, "minor lords", i.e. pipiltin, "common soldiers", i.e. merited warriors or quauhpipiltin, respectively, and, finally, "the commoners", i.e. macehualtin.

The mantles by which Tenochca men distinguished from each other, called tilmatli, were draped garments which acted as capes or cloaks worn around the shoulders and the entire individual's figure, while larger tilmatli (quachtli) were also used as a kind of money. Tilmatli was tied either over the right shoulder (macehualtin) or in front so that the knot lay

24 In the Mexican edition of Durán's Historia the sentence "....in order to distinguish him from the rest" is absent (cf. DURÁN 2002:265).

DOI: 10.2478/eas-2018-0012 C University of SS. Cyril and Methodius in Trnava. All rights reserved. 
over the breastplate (pipiltin). Macehualtin owned two or three tilmatli, pipiltin owned many more (AGUILAR-MORENO 2006:365).

From the above-mentioned laws results that differences of tilmatli worn by tatoani, tlazopipiltin, pipiltin, merited warriors and macehualtin concerned the materials from which the mantles were sewn, their cut (i.e. length), as well as their ornamentation. Thus, macehualtin were prohibited from wearing cotton mantles or mantles longer than to their knees (unless they covered the wounds they had received on battlefield), the mantles of nonnoble warriors with merits had to be simpler than those of pipiltin etc. Some special mantles could wear only tlatoani (such mantles were royal insignia).

Another sumptuary law illustrates that prestige of a Tenochca man depended also on the type of house he lived in:

"8. Only the great noblemen and valiant warriors are given license to build a house with a second story; for disobeying this law a person receives the death penalty. No one is to put peaked or flat or round additions [towers? gables?] upon his house. This privilege has been granted by the gods only to the great. " (DURÁN 1994:209).

In other words, "great noblemen" (pipiltin) and "valiant warriors" (quauhpipiltin), had, contrary to macehualtin, the privilege to live in luxurious houses to which scholars refer as to "palaces".

Pipiltin lived in palaces, either in tlatoani's palace or in their own (smaller) palaces, which, as already mentioned, were at least twelve, and were unevenly distributed throughout Tenochtitlan and Tlatelolco. On the other hand, not all Tenochca elites lived in palaces. Although some tetecuhtin, the state administrators of calpultin recruiting from both pipiltin and quauhpipiltin, may have lived (in respective calpultin) in certain palaces (ROVIRA MORGADO 2011:77ff.), the majority of them seem to have lacked a palace-like housing and resided in the telpochcalli buildings (ALCÁNTARA GALLEGOS 2004:173).

To palaces (tecpan) of pipiltin, who were sometimes tetecuhtin at the same time, were attached some lands, and over time palaces could become, in Tenochtitlan, as well as in other Nahua city-states, autonomous and autarchic social, economical and political units (teccalli) resembling feudal domains (ROVIRA MORGADO 2014). However, in the western Nahua area (Mexican Valley and Mexican state Morelos), where also Tenochtitlan was situated, such palaces/domains participated in local administration exercised on behalf of the state 
(ruler) and were controlled by the state (ruler) to a major extent than in the eastern Nahua area (today Mexican states Puebla and Tlaxcala) (LOCKHART 1992:102ff.).

There had always been a striking difference between large stone palaces and a lot more smaller, mostly from adobe bricks constructed and considerably poorer equipped houses of macehualtin. Although the physical appearence of palaces was not unified, they had the same basic structure. A palace consisted of a closed rectangular inner court (patio) with a single entrance from ouside and several rooms arranged around the court, which were built in a certain height above the ground level (SMITH 2008:115ff.; TOBY EVANS 2004:7-58).It is worth mentioning that the law we are examining emphasized that the privilege to live in palaces had a divine origin. This statement was connected with a peculiar religious status of pipiltin which provided them - contrastively to macehualtin - with a close relation to gods not only Tenochtitlan rulers, but also pipiltin (rulers' relatives) considered themselves a kind of Huitzilopochtli's and other gods' terrestrial representants, and this already in times of Huitzilihuitl (ruled ca. 1396-1417), the second tlatoani of Tenochtitlan (DURÁN 2002, I:111). No surprise then that such prestigious relation pipiltin intended to demonstrate. Thus, their palaces had a certain greater altitude and vertically, up to celestial gods' world oriented disposition.

The remaining sumptuary laws concerned various jewels, made from e.g. gold, which, similarly as other Tenochca prestige objects, had the social functions outlined above. I will qoute these two laws together:

"9. Only the great lords are to wear labrets, ear plugs, and nose plugs of gold and precious stones, except for commoners who are strong men, brave captains, and soldiers, but their labrets, ear plugs, and nose plugs must be of bone, wood, or other inferior material of little value. “(DURÁN 1994:209).

"10. Only the king of Tenochtitlan and sovereigns of the provinces and other great lords are to wear gold armbands, anklets, and golden rattles on their feet at the dances. They may wear garlands and gold headbands with feathers in them in the style they desire; and no one else may use them. These kings alone may adorn themselves with chains of gold around their necks, with jewelry of this metal and of precious stones, such as jade, all made by master jewellers; and no one else may. Other valiant soldiers who are not considered noblemen may wear common garlands and eagle, macaw, and certain other feathers on their heads. They may adorn themselves with necklaces of bone and of small snails, small scallop shells, bones 
of snakes, and common stones. (Some of the latter, though, were so well polished, carved, and painted that they were very handsome and looked fine.) " (DURÁN 1994:2010). ${ }^{25}$

It is clear that also these sumptuary laws were supposed to reinforce the Tenochca social hierarchy, as well as to manifest supernatural connections between certain deities and human owners of the jewels mentioned in the laws, which unfolded from the symbolism that surrounded the materials from which these jewels were produced, as well as their forms and ornamentantion (BAQUEDANO 2005; JANSEN 1997; LOWE 2004; OLKO 2006; TORRES MONTÚFAR 2015).

As already mentioned, there were a few other sumptuary laws which may or may not have been part of Motecuhzoma's laws. Among these laws were, for example, alimentary prohibitions: macehualtin, contrary to pipiltin, were forbidden, under the pain of death, to consume a cacao beverage (SAHAGÚN 2001, I:609), as well as an alcoholic beverage (pulque) (ALBA 1949:12), having both specific religious meanings and being involved into religious rituals, although it is possible, that during public religious festivals both prohibitions were applied moderately in relation to macehualtin.

\section{Penal laws}

Motecuhzoma's penal laws were the following:

"14. There is to be rigorous law regarding adulterers. They are to be stoned and thrown into the rivers or to buzzards.” (DURÁN 1994:210).

"15. Thieves will be sold for the price of their theft, unless the theft be grave, having been committed many times. Such thieves will be punished by deaths." (DURÁN 1994:210). (cf. DURÁN 2002:266).

DOI: 10.2478/eas-2018-0012 C University of SS. Cyril and Methodius in Trnava. All rights reserved. 
The laws quoted are only two and are formulated quite shortly. This is in a striking contrast with a great complexity of Tenochca penal law (VYŠNÝ 2012:170ff.) and especially a complex legal regulation of adultery (tetlaximaliztli) (VYŠNÝ 2012:193-194) and theft (ychtequiliztli) (VYŠNÝ 2012:198-201) which distinguishes, inter alia, several forms of both crimes regarding the extent of their seriousness etc. It is my hypothesis that the very little attention the legislator (Motecuhzoma I) had paid to penal law was due to a characteristic feature of ancient legal codes, namely their incompleteness. Such codes involved only a certain part of a society's law, while its another part, sometimes even a major part, was a long-term legal tradition (customary law), deep-rooted in a society and observed by the majority of their members, as well as accepted and enforced by the state (ruler, ruling class), and thus it was not necessery to incorporate it to a legal code.

On the other hand, the incorporation of adultery and theft into Motecuhzoma's legal code may point out that these crimes, considered serious, were in Tenochtitlan wide-spread, which could resulted in a need for more systematic and rigorous prosecution and punishment of their perpetrators which only the state (concretely the judiciary) and only clear codified allsociety legal rules enacted and enforced by state could assecurate.

\section{Conclusion}

The laws of Motecuhzoma Ilhuicamina were possibly arranged into a coherent legal code, which seems to have encompassed only a small part of Tenochca law. However, it was an important, even fundamental part, relating to Tenochca complex mechanisms of social control such as: centralized state apparatus theoretically acting on the entire city-state territory and beyond it, throughout the Aztec Empire; social stratification and existence of a privileged tiny ruling class; penal law; state distribution of prestige objects as special rewards of services provided to state by the rewarded, enabling them certain ascension in the social hierarchy; ideology, to which young pipiltin, as well macehualtin (of both sexes) were obligatory introduced in public schools, in order to be able realize it later, especially by taking part in military campaigns and "nourishing of gods" with enemies they had captured on battlefield, and so on. 
Similarly as in many other historical contexts, also in Tenochtitlan was the enactment of a series of law an integral part of the process of state formation. Thus, Motecuhzoma's laws should stabilize and reinforce the Tenochca state as a new complex sociopolitical order. It is nevertheless questionable to what extent they succeeded in it, since their enforcement in Tenochtitlan inhabitants' daily life was rather limited, as was the case, primarily, but not only, of Motecuhzoma's sumptuary laws (probably prior the reign of Motecuhzoma Xocoyotzin). According to these laws was the only distributor of prestige objects the state (i.e. tlatoani) and the acquiring of such objects was determined by e.g. military services provided to distributor, however in practice both pipiltin and macehualtin were gaining some prestige objects on their own, buying them on a market, for example. Motecuhzoma's laws relating to Tenochtitlan state apparatus reflect its hierarchical and centralized character, i.e. local state organs, residing in individual calpultin, were subordinated to and directed by central state organs (tlatoani's palace), but despite of it, was the power of state (tlatoani) sufficiently exercised in calpultin? Namely, a tendency to create local autonomous and autarchic socioeconomic units (not only in Tenochtitlan) occurred, which surely was weakening the state (tlatoani's) power, along with its capability to enforce properly Motecuhzoma's legal code (or other laws enacted by the state). Such units resisted the state power to some degree, which thus probably could not enforce the state law evenly on the entire territory of Tenochtitlan. Situation like this had been common in world legal history since at least the highly-developed and very comprehensive, but never systematically applied Babylonian Code of Hammurabi (18 ${ }^{\text {th }}$ century BC).

The laws of Motecuhzoma Ilhuicamina, as well as Tenochca law as a whole, should be explored in broad context of Tenochca, Nahua and even all-Mesoamerican general history, society and religion. Only to a lesser extent was possible to do this in the present article, but further investigation of pre-Hispanic Nahua law is planned by the author.

\section{Bibliography}

AGUILAR-MORENO, Manuel (2006): Handbook to Life in the Aztec World. [sine loco]: Oxford University Press.

ALBA, Carlos H. (1949): Estudio comparado entre el derecho azteca y el derecho positivo mexicano. México: Instituto Indigenista Interamericano. 
ALCÁNTARA GALLEGOS, Alejandro (2004): Los barrios de Tenochtitlan. Topografía, organización interna y tipología de sus predios. In Gonzalbo P. Escalante (coordinador): Historia de la vida cotidiana en México. Tomo I. Mesoamérica y los ámbitos indígenas de la Nueva España. México: El Colegio de México \& Fondo de Cultura Económica, pp. 167-198.

ANAWALT, Patricia (1980): Costume and Control: Aztec Sumptuary Laws. In Archaeology, Vol. 33, No. 1, pp. 33-43.

BAQUEDANO, Elizabeth (2005): El oro azteca y sus conexiones con el poder, la fertilidad agrícola, la guerra y la muerte. In Estudios de Cultura Náhuatl, No. 36, pp. 359381.

BARLOW. Robert H. (1945): La Crónica X. In Revista Mexicana de Estudios Antropológicos, VII, pp. 65-87.

BERDAN RIEFF, Frances F. - ANAWALT, Patricia (1997): The essential Codex Mendoza. Berkeley: University of California Press.

BERDAN, Frances F., et al. (1996): Aztec Imperial Strategies. Washington, D. C.: Dumbarton Oaks Research Library and Collection.

BERDAN, Frances (2014): Aztec Archaeology and Ethnohistory. New York: Cambridge University Press.

BERDAN, Frances - SMITH, Michael E. (2004): El sistema mundial mesoamericano postclásico. In Relaciones, Vol. XXV, No. 99, pp. 19-77.

BONDARENKO, Dmitri M. (2008): Kinship, Territoriality and Early State Lower Limit. In Social Evolution \& History, Volume 7, Number 1, pp.19-53.

BONDARENKO, Dmitri M. (2014): On the Nature and Features of the (Early) State: An Anthropological Reanalysis. In Zeitschrift für Ethnologie, Vol. 139, No. 2, pp. 215-232.

BOONE, Elizabeth H. (2000): Stories in Red and Black. Pictorial Histories of the Aztecs and Mixtecs. Austin: University of Texas Press.

BOONE, Elizabeth. H. (2007): Cycles of Time and Meaning in the Mexican Books of Fate. Austin: University of Texas Press.

BOURDIEU, Pierre (1998): Teorie jednání. Praha: Karolinum.

BREUER, Stefan (1988): Imperien der Neuen Welt? Zur Klassifikation des Inka- und Aztekenstaates. In Saeculum. Jahrbuch für Universalgeschichte, Vol. 39, issue 1, pp. 35-62.

BRODA, Johanna (1977): Estratificación social y ritual mexica. Un ensayo de Antropología Social de los mexica. In Indiana 5, pp. 45-81.

DOI: 10.2478/eas-2018-0012 C University of SS. Cyril and Methodius in Trnava. All rights reserved. 
BRODA, Johanna (1978): Relaciones políticas ritualizadas: El ritual como expresión de una ideología. In Pedro Carrasco - Johanna Broda (editores): Economía política e ideología en el México prehispánico. México: Editorial Nueva Imagen, pp. 221-255.

BRUMFIEL, Elizabeth M. (1983): Aztec State Making: Ecology, Structure, and the Origin of the State. In American Anthropologist, Vol. 85, No. 2, pp. 261-284.

BRUMFIEL, Elizabeth M. (2000): The politics of high culture: issues of worth and rank. In Janet Richards - Mary van Buren (eds.): Order, legitimacy and wealth in ancient states. Cambridge: Cambridge University Press, pp. 131-139.

CASTAÑEDA DE LA PAZ, María (2005): Itzcoátl y los instrumentos de su poder. In Estudios de Cultura Náhuatl, No. 36, pp. 115-147.

CARRASCO, Pedro (1978): La economía del México prehispánico. In Pedro Carrasco - Johanna Broda (editores): Economía política e ideología en el México prehispánico. México: Editorial Nueva Imagen, pp. 13-76.

CARRASCO, Pedro (1996): Estructura político-territorial del Imperio tenochca. La Triple Alianza de Tenochtitlan, Tetzcoco y Tlacopan. México: Fondo de Cultura Económica.

CARRASCO, Davíd (1998): Náboženství Mezoameriky. Kosmovize a obřadní centra. Praha: Prostor.

CHASE, Arlen F. - CHASE, Diane Z. - SMITH, Michael E. (2009): States and Empires in Ancient Mesoamerica. In Ancient Mesoamerica 20, 2009, pp. 175-182.

CLAESSEN, Henri J. M. - SKALNÍK, Peter (1978): The Early State: Models and Reality. In Henri J. M. Claessen - Peter Skalník (eds.): The Early State. The Hague: Mouton Publishers, 1978, pp. 637-650.

CLAESSEN, Henri J. M. (1998): Lawgiving and the Administration of Justice in Some African and other Early States. In African Studies Quaterly, Vol. 2, Issue 3, pp. 27-36.

CLAESSEN, Henri J. M. (2010): On Early States - Structure, Development, and Fall. In Social Evolution \& History, Vol. 9, No. 1, pp. 3-51.

CLAVIJERO, Francisco Javier (2003): Historia antigua de México. México: Porrúa.

DURÁN, Diego (1994): The History of the Indies of New Spain. Translated, Annotated, and with an Introduction by Doris Heyden. Norman and London: University of Oklahoma Press.

DURÁN, Diego (2002): Historia de las Indias de Nueva España e Islas de Tierra Firme, I. México: Consejo Nacional para la Cultura y las Artes.

DURÁN, Diego (2002): Historia de las Indias de Nueva España e Islas de Tierra Firme, II. México: Consejo Nacional para la Cultura y las Artes.

DOI: 10.2478/eas-2018-0012 C University of SS. Cyril and Methodius in Trnava. All rights reserved. 
PETER VYŠNÝ

The Laws of Motecuhzoma Ilhuicamina

FLORESCANO, Enrique (1999): Memoria indígena. México: Taurus, 1999.

GARIBAY K., Ángel Ma (2007): Historia de la literatura náhuatl. México: Porrúa.

GILLESPIE, Susan D. (1993): Los reyes aztecas. La construcción del gobierno en la historia mexica. México: Siglo Ventiuno.

GRAULICH, Michel (1999): Ritos aztecas: las fiestas de las veintenas. México: Instituto Nacional Indigenista.

GRININ, Leonid E., et al., (eds.): The Early State, its Alternatives and Analogues. Volgograd: Uchitel Publishing House.

GRININ, Leonid E. - KORATAYEV, Andrey V. (2012): Emergence of Chiefdoms and States: A Spectrum of Opinions. In Social Evolution \& History, Vol. 11, No. 2, pp. 191204.

HINZ, Eike (1990): Das Aztekenreich: Soziale Gliederung und institutioneller Aufbau. In Ulrich Köhler (Hrsg.): Altamerikanistik. Eine Einführung in die Hochkulturen Mittel- und Südmerikas. Berlin: Dietrich Reimer Verlag, 1990, pp. 189-205.

HINZ, Eike (2002): Mesoamerikanistik als Sozialwissenschaft: Soziale Evolution, soziales System, soziales Verhalten und soziale Kognition in Mesoamerika. Hamburg: Wayasbah, 2002.

JANSEN, Maarten (1997): Símbolos de poder en el México antiguo. In Anales del Museo de América 5, pp. 73-102.

JOHNSON, Allen W. - EARLE, Timothy (2000): The Evolution of Human Societies. From Foraging Group to Agrarian State. Second Edition. Stanford: Stanford University Press.

KALYUTA, Anastasia (2008): La casa y hacienda de un señor mexica: Un estudio analítico de la "Información de doña Isabel de Moctezuma". In Anuario de Estudios Americanos 65, 2, pp. 13-37.

KATZ, Friedrich (1956): Die sozialökonomischen Verhältnisse bei den Azteken im 15. und 16. Jahrhundert. In Ethnographisch-Archäologische Forschungen, 3 (2), pp. 9-166.

KATZ, Friedrich (1989): Staré americké civilizace. Praha: Odeon.

KOVÁČ, Milan (2002): SInko jaguára. Náboženský svet Olmékov, Mayov a Aztékov. Bratislava: Chronos.

KRADIN, Nikolay N. (2009): State Origins in Anthropological Thought. In Social Evolution \& History, Vol. 8, No. 1, pp. 25-51. 
KURTZ, Donlad V. (1978): The Legitimation of the Aztec State. In Henri J. M. Claessen - Peter Skalník (eds.): The Early State. The Hague: Mouton Publishers, pp. 169-190.

Las literaturas indígenas (1985): Estudio introductorio, selección y notas de Miguel León-Portilla. México: Promexa.

LEÓN-PORTILA, Miguel (1993): La Filosofía Náhuatl estudiada en sus fuentes. México: Universidad Nacional Autónoma de México.

LEÓN-PORTILLA, Miguel (2003): Toltecáyotl. Aspectos de la cultura náhuatl. México: Fondo de Cultura Económica.

LEÓN-PORTILLA, Miguel, et. al. (2013): Historia documental de México, I. México: UNAM, Instituto de Investigaciones Históricas.

LOCKHART, James (1992): The Nahuas After the Conquest. A Social and Cultural History of the Indians of Central Mexico, Sixteenth Through Eighteenth Centuries. Stanford: Stanford University Press.

LÓPEZ AUSTIN, Alfredo (1961): La Constitución Real de México-Tenochtitlan. México: Universidad Nacional Autónoma de México, Instituto de Historia.

LÓPEZ AUSTIN, Alfredo (1998): Hombre-Dios. Religión y política en el mundo náhuatl. México: UNAM, Instituto de Investigaciones Históricas.

LÓPEZ AUSTIN, Alfredo - LÓPEZ LUJÁN, Leonardo (1999): Mito y realidad de Zuyuá. Serpiente Emplumada y las transformaciones mesoamericanas del Clásico al Posclásico. México: El Colegio de México.

LÓPEZ AUSTIN, Alfredo - LÓPEZ LUJÁN, Leonardo (2014): El pasado indígena. México: El Colegio de México.

LOWE, Lynneth S. (2004): Los bezotes como símbolos de jerarquía militar en el México antiguo. In Estudios Mesoamericanos, Núm. 6, pp. 48-54.

MANN, Michael (1986): The Autonomous Power of the State: Its Origins, Mechanisms and Results. In John A. Hall (ed.): States in History. Oxford, New York: Basil Blackwell, pp. 109-136.

MANN, Michael (2008): Infrastructural Power Revisited. In Studies in Comparative International Development 43, pp. 355-365.

NAVARRETE LINARES, Federico (1997): Medio siglo de explorar el universo de las fuentes nahuas: Entre la historia, la literatura y el nacionalismo. In Estudios de Cultura Náhuatl, No. 27, pp. 155-179. 
OFFNER, Jerome A. (2017): The Future of Aztec Law. In Elizabeth Lambourn (ed.): Legal Encounters On The Medieval Globe. Medieval Globe, 2. Kalamazoo, Michigan: Arc Humanities Press, pp. 1-32.

OLKO, Justyna (2006): Traje y atributos del poder en el mundo azteca: significados y funciones contextuales. In Anales del Museo de América 14, pp. 61-88.

OLKO, Justyna (2011): Supervivencia de los objetos de rango prehispánicos entre la nobleza colonial nahua. In Revista Española de Antropología Americana, Vol. 41, No. 2, pp. 455-469.

OLKO, Justyna (2014): Insignia of Rank in the Nahua World: From the Fifteenth to the Seventeenth Century. Boulder: University of Colorado Press.

PAREDES GUDIÑO, Blanca (1986): La unidad habitacional en la cuenca de México: periodo Postclasico. In Linda Manzanilla, (ed.): Unidades habitacionales mesoamericanas y sus areas de actividad. México: UNAM, pp. 221-256.

PEPERSTRAETE, Sylvie (2007): La "Chronique X" : Reconstitution et analyse d'une source perdue fondamentale sur la civilisation Aztèque, d'après I' Historia de las Indias de Nueva España de D. Durán (1581) et la Crónica Mexicana de F. A. Tezozomoc (ca. 1598). Oxford: Archeopress.

PLOURDE, Aimée M. (2008): The Origins of Prestige Goods as Honest Signals of Skill and Knowledge. In Human Nature 19, 4, pp. 374-388.

RECASENS SICHES, Luis (2003): Historia de las doctrinas sobre el contrato social. México: UNAM.

REYES GARCÍA, Luis (1996): El término calpulli en documentos del siglo XVI. In Luis Reyes García, Luis, et al.: Documentos nauas de la Ciudad de México del siglo XVI. México: Secretaría de Gobernación, pp. 21-68.

ROVIRA MORGADO, Rossend (2011): In Chalchihuitl in Quetzalli: Nobleza urbana, residencias palaciegas y rentas nobiliarias en México-Tenochtitlan. In Gabriela Dalla Corte et al. (coordinadores): Sociedades diversas, sociedades en cambio. América Latina en perspectiva histórica. XII Encuentro-debate América Latina ayer y hoy. Barcelona: Universitat de Barcelona, 2011, pp. 75-85.

ROVIRA MORGADO, Rossend (2014): Las cuatro parcialidades de MéxicoTenochtitlan: especialidad prehispánica, construcción virreinal y prácticas judiciales en la Real Audiencia de la Nueva España (siglo XVI). Doctoral thesis. Universidad Autónoma de Madrid, Departamento de Historia Moderna. Published online: https://repositorio.uam.es/handle/10486/662979 (accessed January 31, 2018). 
ROZAT DUPEYRON, Guy (1993): Indios imaginarios e indios reales: en los relatos de la conquista de Mexico. México: Tava.

SAHAGÚN, Bernardino de (2001): Historia general de las cosas de la Nueva España, I. Madrid: Dastin.

SAHAGÚN, Bernardino de (2001): Historia general de las cosas de la Nueva España, II. Madrid: Dastin.

SAHAGUN, Bernardino de (1974): Florentine Codex. General History of the Things of New Spain. Book 8 - Kings and Lords. Part IX. Santa Fe: The School of American Research and The University of Utah.

SAHAGUN, Bernardino de (1979): Florentine Codex. General History of the Things of New Spain. Book 10 - The People. Part XI. Santa Fe: The School of American Research and The University of Utah.

SALOMONS, Carolyn (2006): Hybrid Historiography: Pre- and Post-conquest Latin America and Perceptions of the Past. In Past Imperfect, 12, pp. 1192-1315.

SMITH, Michael E. (2008): Aztec City-States Capitals. Gainesville: University Press of Florida.

SMITH, Michael E. (2012): The Aztecs. Hoboken, NJ: Wiley - Blackwell.

SULLIVAN, Thelma D. (1980): Tlatoani and Tlatocayotl in the Sahagun Manuscripts. In Estudios de Cultura Náhuatl, No. 14, pp. 225-238.

TAUBE, Karl A. (2012): The symbolism of turquoise in ancient Mesoamerica. In Jonathan C. H. King et al. (eds.), Turquoise in Mexico and North America: Science, Conservation, Culture and Collections. London: Archetype, pp. 117-134.

TENA, Rafael (1997): Revisión de la hipótesis sobre la crónica X. In Salvador Rueda Smithers et al. (eds.): Códices y documentos sobre México, Segundo Simposio Internacional. México: INAH, Vol. 2, pp. 163-178.

TENA, Rafael (2006): Las Antigüedades mexicanas de fray Andrés de Olmos. In Luis Barjau (coord.): Etnohistoria. Visión alternativa del tiempo. México: INAH, pp. 29-37.

TEZOZOMOC, Fernando de Alvarado (1998):Crónica Mexicáyotl. México: UNAM, Instituto de Investigaciones Históricas.

TEZOZOMOC, Hernando de Alvarado (1997): Crónica Mexicana. Madrid: Historia 16 Información e Historia, S. L.

TOBY EVANS, Susan (2004): Aztec Palaces and Other Elite Residential Architecture. In Susan Toby Evans - Joanne Pillsbury (eds.): Palaces of the Ancient New World. 
A Symposium at Dumbarton Oaks 10th and 11th October 1998. Washington: Dumbarton Oaks Research Library and Collection, pp. 7-58.

TRIGGER, Bruce G. (2007): Understanding Early Civilizations: A Comparative Study. New York: Cambridge University Press.

VYŠNÝ, Peter (2012): Štát a právo Aztékov. Trnava: Typi Universitatis Tyrnaviensis.

WOOD, Stephanie (1998): The Social vs. Legal Context of Nahuatl Títulos. In Elizabeth Hill Boone - Thomas B. F. Cummins (eds.): Native Traditions in the Postconquest World. Washington, D. C.: Dumbarton Oaks Research Library and Collection, pp. 201-231.

ZORITA, Alonso de (1963): Breve y Sumaria Relación de los Señores de la Nueva España. México: UNAM.

ZANTWIJK, Rudolf van (1980): El carácter de la autoridad en el Imperio Azteca y su expresión en la retórica oficial. In Indiana 6, 1, pp. 71-87. 